\title{
Pandeglang regency spatial evaluation based on tsunami hazard potential
}

\author{
Roihan Nauval Majid ${ }^{1}$ and Triarko Nurlambang ${ }^{1, *}$ \\ ${ }^{1}$ Department of Geography, Universitas Indonesia, Indonesia
}

\begin{abstract}
Abstarct.The coastal area of Pandeglang Regency is one area that has the potential to be affected by the tsunami. The existence of the Krakatau Anak Volcano and plate subduction paths in the Sunda Strait cause Pandeglang Regency to become one of the regions that has a tsunami potential. One of the steps to anticipate the tsunami disaster is to do spatial planning that has considered the potential tsunami hazard. The purpose of this research is to evaluate the spatial area of Pandeglang Regency based on the identification of potential tsunami hazards. The identification of potential tsunami hazards is done by modeling the potential distribution of tsunami wave heights in coastal areas using GIS modeling. The results of the identification of potential tsunami hazards on the coast of Pandeglang Regency showed that an area of 194.15 hectares of residential land and the location of existing activities had the potential to be affected by the tsunami. The total area of the coastal area of Pandeglang Regency which was potentially affected by the tsunami hazard reached 1483.26 hectares. The results of a review of the Pandeglang Regency's spatial plan showed that 488.22 hectares of land were found in the planned residential spatial patterns that were potentially affected by the tsunami. Therefore, the regional spatial plan of Pandeglang Regency in the study area needs to be evaluated by changing the function of residential land that has the potential to be affected by the tsunami hazard to the border of the beach or other open land.
\end{abstract}

\section{Introduction}

Tsunami is one of natural disaster that can have a huge impact on coastal areas. Based on EM-DAT recording data in the Tsunami Disaster Risk 2016 book, 16 major tsunami events resulted in deaths of up to 250,900 people in 21 countries from 1996 to 2015 [4]. Tsunamis triggered by earthquakes, volcanic eruptions, and landslides on the sea floor. Indonesia is one country that has a large tsunami risk. This is because the territory of Indonesia in subduction zones and faults, so that Indonesia is one of the countries with the highest tectonic activity in the world [7]. This tectonic activity causes a high risk of tsunamis in Indonesia. The tsunami that occurred in Indonesia was 90.5 percent caused by earthquakes in the sea; 8.6 percent triggered by volcanic eruptions at sea; and 1 percent triggered by landslides in the sea [3]. Until 2012 there were at least 22 regions in Indonesia that were recorded as having experienced a tsunami disaster [3]. The magnitude of the tsunami disaster risk in Indonesia especially in coastal areas needs to be anticipated in order to minimize losses due to the tsunami disaster. Coastal area mitigation strategies have been regulated in Indonesia's Constitution number 27 of 2007, concerning the management of coastal areas and small islands. Written in the constitution that one of the steps to anticipate the tsunami disaster is to conduct spatial planning that has considered the risks of tsunami hazards.

\section{Theory}

\subsection{Tsunami hazard analysis}

Tsunamis are a series of seawater waves that can propagate at speeds reaching more than $900 \mathrm{~km} / \mathrm{h}$ or more in the middle of the sea [2]. One of the tsunami events that has occurred in Indonesia was the tsunami incident around the province of Aceh in 2004. This tsunami was caused by an earthquake in the Indian Ocean of $9.2 \mathrm{SR}$ with a depth of $30 \mathrm{~km}$ [9]. Other tsunami events in Indonesia occurred in Palu City, Sulawesi in September 2018 with tsunami height reaching 8 meters and inundation distances of up to 50 meters from the coast due to the 7.5 SR earthquake [1]. The victims from the Palu tsunami reached 212,719. While the recent tsunami in Indonesia was a tsunami in Banten and Lampung due to avalanches from the Anak Krakatau Volcano eruption [11]. Based on reports from the Indonesia's National Disaster Management Agency (BNPB), the tsunami resulted in 41,132 people being affected.

The importance of tsunami disaster management in Indonesia was responded to through the Republic Indonesia Constitutions (UU) No. 24 of 2007 related to disaster relief, including tsunami disaster management. Where one of the stages in the implementation of disaster management is by carrying out disaster management planning. Disaster management planning is based on the magnitude of the disaster related hazards.

\footnotetext{
$\overline{\text { * Corresponding author: triarko@gmail.com }}$
} 
Determining the magnitude of the danger of a disaster, especially in the context of a tsunami disaster, one method commonly used is a mathematical approach [5] [6] [13]. BNPB calculates the tsunami hazard in an area based on a mathematical approach by calculating the distribution of maximum tsunami potential. The equation used in the mathematical approach used is the equation developed by Barryman (2006). Barryman calculates tsunami hazards based on variations in roughness and slope of the surface. The equation developed by Barryman is as follows.

$$
H_{\text {loss }}=\left(\frac{167 n^{2}}{H_{0}^{\frac{1}{2}}}\right)+5 \sin S
$$

where:

$\begin{array}{ll}\mathrm{H}_{\text {loss }} & \begin{array}{l}\text { is loss of tsunami height per } 1 \mathrm{~m} \text { inudation } \\ \text { distance }\end{array} \\ \mathrm{n} & \text { is surface roughness coefficient } \\ \mathrm{H}_{\mathrm{o}} & \text { is tsunami wave height on the coastline (m) } \\ \mathrm{S} & \text { is surface slope (degree) }\end{array}$

The surface roughness coefficient is based on the cover / land use using the following classification.

Table 1. Surface coefficients of each classification of land cover / land use

\begin{tabular}{lc}
\hline \hline \multicolumn{1}{c}{ Land cover / Land Use } & $\begin{array}{c}\text { Surface Roughness } \\
\text { Coefficient }\end{array}$ \\
\hline \hline Water & 0,007 \\
Shrubs / Bushes & 0,040 \\
Forest & 0,070 \\
Plantataion & 0,035 \\
Open Land & 0,015 \\
Agricultural land & 0,025 \\
Built-in Settlements / Land & 0,045 \\
Mangrove & 0,025 \\
Ponds & 0,010 \\
\hline \hline
\end{tabular}

(source: Berryman, 2006, in Risiko Bencana Indonesia, 2015)

\subsection{Spatial Planning Policy}

Spatial planning based on Republic of Indonesia Constitution number 26 of 2007 is a process in determining the structure and pattern of space which includes the stages of preparation and determination of spatial plans. Spatial structure is the arrangement of residential centers and network systems of infrastructure and facilities that function as supporters of the socioeconomic activities of the community that have a functional relationship hierarchically, while the spatial pattern is the distribution of allotment space in an area which includes spatial allocation for the function of cultivation.

Policies and strategies for developing spatial structures and patterns in the formulation of spatial plans based on Indonesian Government Regulations (Peraturan Pemerintah) number 26 of 2008 divide each region into three regions, namely protected areas, cultivation areas, and strategic areas. Regions can determine land use based on the main function of the region. Protected areas are areas that have a primary function to protect the preservation of the environment which includes natural resources and artificial resources. Cultivation area is an area that is intended to be cultivated because of the conditions and potential of natural resources, human resources, and artificial resources. National strategic areas are priority areas because their influence is very important nationally.

Tsunami prone areas fall into the category of disaster-prone areas. Based on Republic of Indonesia Constitution number 24 of 2007, disaster-prone areas by definition are areas with the main function of protection or cultivation that have geological, biological, hydrological, climatological, geographical, social, cultural, political, economic, and technological conditions in a region for a certain period of time which reduces the ability to prevent, reduce, achieving readiness, and reducing the ability to respond to the adverse effects of certain hazards. In Indonesian Government Regulations number 13 of 2017, disasterprone areas are defined as areas that can be used as cultivation activities, but there must be criteria for limiting the allowable cultivation activities. In Republic of Indonesia Constitution number 27 of 2007, the area of protection against earthquakes and / tsunamis is determined as a coastal border. Therefore, tsunami prone areas are included in coastal border areas.

Spatial planning at the border of a tsunami-prone beach has limitations in the use of space. One limitation of the applicable space utilization in coastal border areas is infrastructure development (Minister of Public Works Indonesia). Spatial planning at the border of a tsunamiprone beach has limitations in the use of space. One of the limitations of the space utilization that applies in coastal border areas is infrastructure development. In addition, there are several spatial planning strategies that need to be implemented to reduce the risk of damage and losses in tsunami-prone areas. These strategies include:

- Determine tsunami prone areas as utilization of open areas;

- Search for tsunami prone areas for the use of open areas;

- Limiting development through land use regulations;

- Prevention of the use of densely populated dwellings.

The open area referred to is intended as an agricultural area, a parking and recreation area, or a disaster-prone area. A broader definition of open areas is also listed in Regulation of the Minister of Public Works (Permen PU) number 5 of 2008, where open areas are one form of open space, which is basically without buildings. Open space is divided into two, namely green open space and non-green open space (Minister of Public Works Indonesia).

\subsection{Area Study}

One of the areas potentially affected by the tsunami in Indonesia is the coastal area of the Pandeglang Regency [9]. The existence of the Anak Krakatau Volcano and the 
Sunda Strait subduction pathway causes Pandeglang District to be one of the areas that has the potential for tsunami [8] [12] [14]. In addition, a number of historical records regarding the tsunami incident in the Sunda Strait and the track record of the earthquake in the Sunda Strait strengthened the potential of tsunamis in the coastal area of Pandeglang Regency [14] [8].

In 2018, coastal area of Pandeglang Regency was affected by the tsunami disaster in the Sunda Strait due to avalanches from the Anak Krakatau volcanic eruption [11]. As a result, based on reports from the BNPB as many as 41,132 people were victims of the tsunami disaster. Therefore, the Pandeglang district was made as a research study area with a focus on areas that were proven to be affected by the Sunda Strait Tsunami incident covering five districts, namely Panimbang, Sukaresmi, Pagelaran, Labuan, and Carita Districts.

Location of the study area is shown in Fig. 1. The study area includes $282.3 \mathrm{~m}^{2}$ land area with a coastline of $63.76 \mathrm{~m}^{2}$ in Pandeglang Regency. The type of cover / land use near the beach is dominated by houses, ponds and rice fields. The pattern of surface elevation around the coast is relatively flat, but in the southern part of the study area there are highlands close to the coast. Calculation of inundation model using the assumption of tsunami height on the coastline used for Pandeglang Regency based on the literature is $11,7 \mathrm{~m} \mathrm{[10].}$

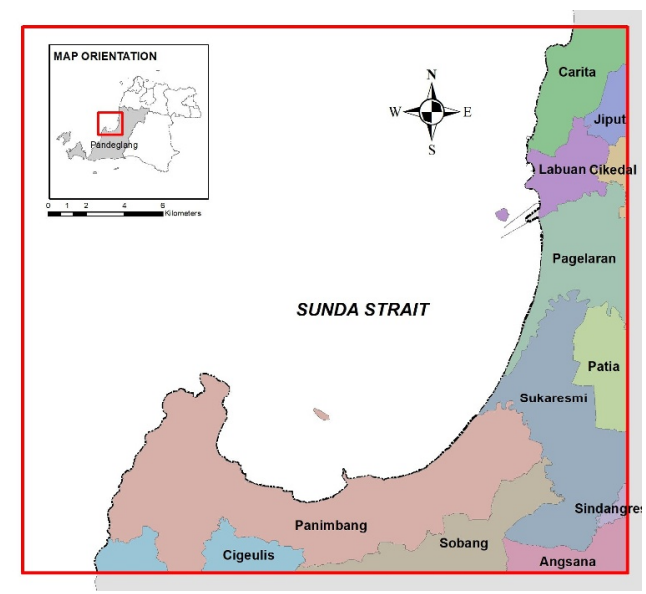

Fig. 1. Focus area of study area on Pandeglang Regency, Indonesia

\section{Method}

The method used in evaluation spatial plans in areas prone to tsunami disasters is GIS modeling method. Identification of areas prone to exposure to tsunami disasters is done by modeling the potential of tsunami wave height distribution in coastal areas.

\subsection{Determination of Tsunami Hazard Areas}

Determination of tsunami hazard areas is carried out by identifying tsunami inundation areas along with the maximum tsunami height in the coastal area of the study area. Data processing uses ArcGIS 10.2 software by building a tsunami run-up calculation model based on a model developed by Barryman (2006) to determine the characteristics of tsunami flow on land. The construction of the model in this study uses the assumption of a tsunami coastline (H0) based on Head Regulation (PERKA) BNPB No.4 of 2012. Furthermore, the determination of the surface roughness coefficient is obtained by converting the land cover / use map and the built environment from the 1: 25,000 scale RBI (Indonesian Earth) map with data updates by google earth data and the OpenStreet Map to the land roughness map in raster format based on the coefficient values in Table I. In addition, spatial slope information is generated from a DEM (Digital Elevation Model) map provided by the DEMNAS with a resolution of 5 meters for each grid. These data are then processed mathematically to obtain $\mathrm{H}$-loss values for each raster grid. The information expected from the model is the classification of areas that have the potential to be affected by the tsunami and those that are not spatially affected.

\subsection{Spatial Planning Evaluation}

Evaluation of spatial patterns planing in potentially tsunami-affected areas is based on the existence of residential land use in the tsunami hazard area and the existing conditions of spatial layout in the coastal area of Pandeglang Regency. This stage is carried out by overlaying between inundation areas and spatial plans of Pandeglang Regency to obtain the total area of the study area spatial plan which is potentially affected by tsunami hazard. The results of the analysis are then expected to produce areas that need to be evaluated from the spatial plan of the study area with spatial evaluation based on tsunami hazard potential.

\section{Result and Discussion}

The results of the calculation of the potential distribution of tsunami inundation heights in the study area with the classification of hazard potential index based on the tsunami inundation potential height are displayed in the tsunami hazard map in the study area as follows.

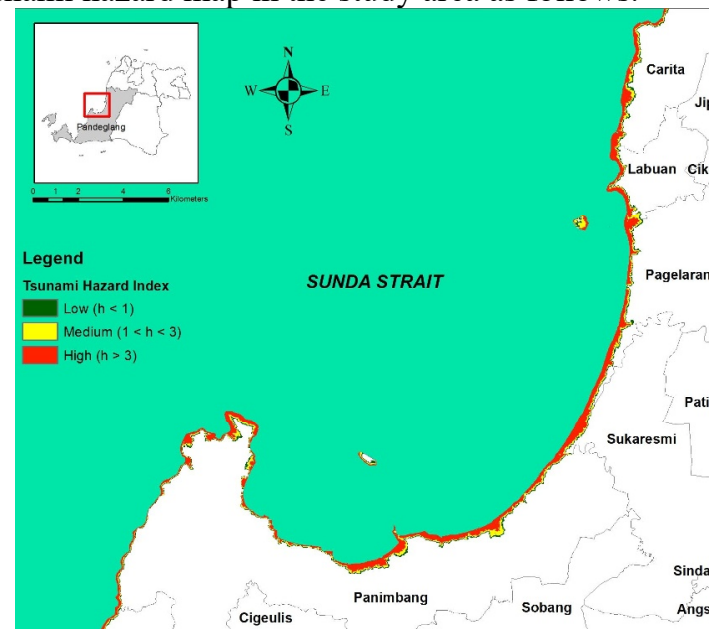

Fig. 2. Potential distribution of tsunami hazard index in the study area 
The results from modeling the distribution of potential tsunami hazards in the study area show that the land area of 1483.26 hectares has the potential to be affected by the tsunami. The distance of tsunami inundation varies and the maximum distance of the tsunami inland towards the land reaches 780 meters.

\subsection{Model Validation}

The Sunda Strait tsunami incident on 22 December 2018 which affected the study area was used as a benchmark in validating the performance of the Barryman equation for the creation of tsunami inundation estimation models. The parameter used as a comparison is the total area of the tsunami inundation that reached the mainland. The extent of the tsunami inundation in the Sunda Strait tsunami incident was obtained from manual interpretation of aerial photographs after the tsunami disaster by drones with high-resolution cameras in the two tsunami-affected areas. Interpretation of the distance of a tsunami runway is based on changes in physical shape of land cover or the presence of material that is expected to result from tsunami flow.

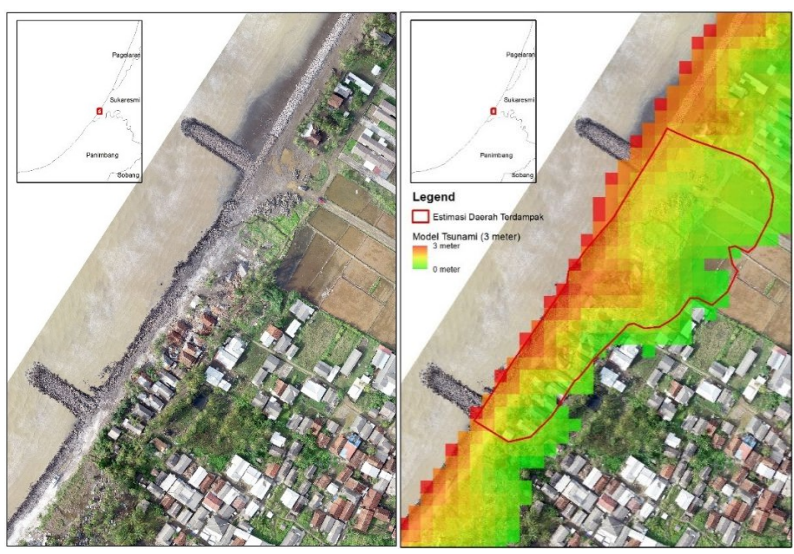

(a)

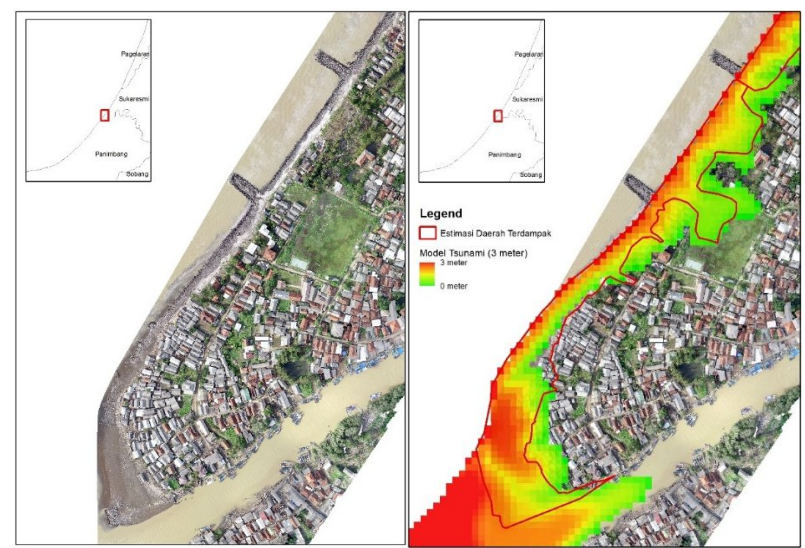

(b)

Fig. 3. Comparison between the results of interpretations of areas affected by the Sunda Strait tsunami with the tsunami model at two locations ((a) and (b)) affected by the tsunami (source: http://inarisk.bnpb.go.id/tsunami_selatsunda/)

Validation results show that the tsunami flow model using the Berryman equation with the assumption of a 3 meter tsunami wave height on the coastline can represent the tsunami flow estimate quite well. The inundation area of the Sunda Strait Tsunami in the review area in Fig. 3 is 4.9 hectares, while the inundation area in the tsunami flow model is 6.23 hectares. however, the tsunami flow model can represent a fairly good tsunami flow pattern when compared to the tsunami flow pattern in the Sunda Strait tsunami events.

\subsection{Tsunami Hazard on Spatial Planning}

A review of the potential impacts of the tsunami hazard on regional spatial planning in Pandeglang was carried out through a digitalized data overlay process from the spatial plan in force in the study area with a potential tsunami hazard. The following is a map of the results of a spatial plan review in a tsunami hazard area.

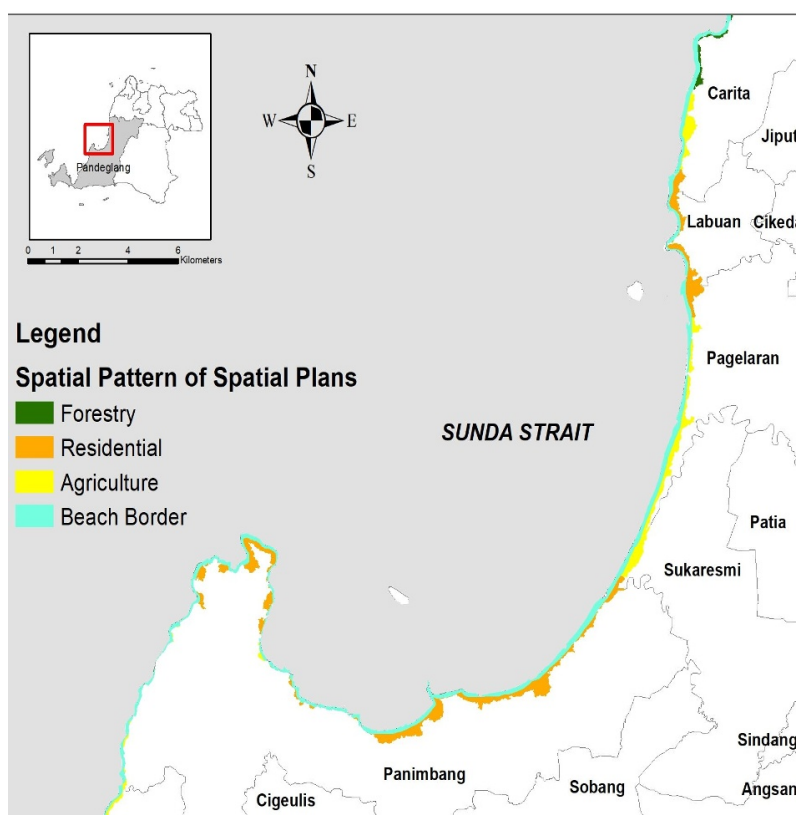

Fig. 4. Spatial Plan of Pandeglang Regency which has the potential to be affected by tsunami hazard

The area of each spatial pattern that has the potential to be affected based on the overlay of the RTRW data with the area of potential tsunami-affected hazards in Fig. 4 is described in the following table.

Table 2. The area of the Spatial Plan of Pandeglang Regency which has the potential to be affected by tsunami hazard

\begin{tabular}{lc}
\hline \hline \multicolumn{1}{c}{ Spatial Pattern } & Total Area \\
\hline \hline Agriculture & 235,6 \\
Residential & 488,22 \\
Forestry & 30,58 \\
Beach Border & 728,87 \\
\hline \hline
\end{tabular}

The results of an overlay analysis between the spatial pattern of the spatial plan and the potential tsunami hazard in Table 2 show that there are 488.22 hectares of residential land in the study area located in the potential tsunami hazard so that it is not in accordance with the rules of spatial planning based on disaster hazard and need to be evaluated. 


\subsection{Spatial Planning Evaluation}

A review of spatial plans in the study area of Pandeglang Regency over potential tsunami hazards shows that the coastal areas in Panimbang District, Sukaresmi District, and Labuan District have residential land located in areas with a potential tsunami hazard. Therefore, the spatial planning in the coastal areas of the sub-district needs to be evaluated by changing the spatial plan pattern of settlements in areas potentially affected by tsunamis to open areas or expanding the coastline to the land. As for Carita District, there is no settlement space pattern in the spatial plan located in a potential tsunami hazard area. This is because the Carita area is used as a beach tourism area.

The existence of a settlement pattern in the Pandeglang district spatial plan that has the potential to be affected by the tsunami hazard can be caused because in the coastal area of Pandeglang Regency it is a place of economic center for fishermen and coastal tourism activities. The spatial plan was prepared after the community was built, so that the prevailing spatial planning takes into account the conditions in which the rules regarding spatial planning do not yet apply. Therefore, the spatial pattern plan in the coastal areas in several sub-districts contained the residential spatial pattern in the spatial plan located in a potential tsunami hazard area.

\section{Conclusion}

The results of the analysis of the potential for tsunami hazard in the study area in Pandeglang District showed that in the study area of this study there was an area of 1483.26 hectares which had a potential tsunami hazard. The tsunami hazard has the potential to be damped on 194,15 hectares of residential land. Among the dense settlements are on the coast of Penimbang District, Sukaresmi District and Labuan District.

A review of the regulations and literature study explains that the types of land use in the spatial plan that are suitable for areas that have a potential tsunami hazard are the coastline and open land, while the types of land use that are not suitable are settlements and buildings. A review of the impact of the potential tsunami hazard on the regional spatial plan of Pandeglang District showed that an area of 488.22 hectares planned residential space patterns and places of activity were potentially affected by the tsunami hazard. Therefore, based on a review of land suitability for potential tsunami hazards, an area of 488.22 hectares of spatial plan in the Pandeglang Regency RTRW is not in accordance with the potential tsunami hazard that exists and needs to be considered for conversion to function as coastal borders or other open land.

\section{References}

1. A. Muhary, J. Disast. Research. 13 (2018)

2. BNPB. Buku Saku: Tanggap Tangkas Tangguh Menghadapi Bencana. (2017)

3. BNPB. Masterplan Pengurangan Risiko Bencana Tsunami. (2012)

4. Centre for Research on the Epidemiology of Disasters (CRED). 2016. Tsunami Disaster Risk 2016: Past Impact and Projection (2016)

5. G.M. Smart, et al. Estimating Tsunami Run-Up. Nat Haz. 80, 1933-1947. (2016)

6. K. Berryman, Review of Tsunami Hazard and Risk in New Zealand. (2005)

7. Latief, Hamzah., J. Nat. Dis. Sci. 22, 25-43 (2000)

8. M.K. Soleman, F. Nurcahyani, S.L. Munajati., J. Globe 14 45-59. (2012)

9. M.R. Amri, et al. Risiko Bencana Indonesia. (2016)

10. N. Horspool, et al. A National Tsunami Hazard Assessment fot Indonesia. Australian AID. (2013)

11. R. Williams., Indonesian tsunami. (2019)

12. S. Prawiradisastra, Jurnal Alami 10, 58-62 (2005)

13. S.C. Selvan, \& R. Kankara., Int. J. Ocean and Clim. Sys., 62-69 (2016)

14. T. Giachetti., J. Geol Soc., 361, 79-90 (2012) 